\title{
LINGKUNGAN KELUARGA, TEKANAN TEMAN SEBAYA DAN PERILAKU BERISIKO REMAJA DI KOTA BANDUNG
}

\author{
Rizkyah Intannia, Tina Hayati Dahlan, Lira Fessia Damaianti \\ Departemen Psikologi, Universitas Pendidikan Indonesia \\ Jalan Doktor Setiabudhi No. 229, Sukasari, Bandung, Jawa Barat 40154 \\ E-mail: rizkytaniia@gmail.com
}

\begin{abstract}
ABSTRAK
Penelitian ini bertujuan untuk mengetahui kontribusi lingkungan keluarga dan tekanan teman sebaya terhadap perilaku berisiko remaja di Kota Bandung. Metode penelitan yang digunakan adalah metode kuantitatif dengan responden sebanyak 486 remaja berusia 13-18 tahun di Kota Bandung. Instrumen yang digunakan dalam penelitian yaitu adaptasi dari Family Environment Scale untuk mengukur lingkungan keluarga, Peer Pressure Inventory untuk mengukur tekanan teman sebaya, dan Negative Risk Behaviour Scale untuk mengukur perilaku berisiko. Teknik analisis data yang digunakan yaitu regresi berganda. Hasil yang diperoleh menunjukkan bahwa terdapat pengaruh lingkungan keluarga dan tekanan teman sebaya terhadap perilaku berisiko. Hasil penelitian ini diharapkan dapat digunakan sebagai acuan bagi keluarga dan para orang tua dalam pentingnya menciptakan lingkungan yang positif dalam kehidupan keluarga bagi anak-anaknya sebagai salah satu upaya preventif terhadap terjadinya perilaku berisiko pada remaja.
\end{abstract}

Kata Kunci: lingkungan keluarga; perilaku berisiko; remaja; tekanan teman sebaya.

\section{FAMILY ENVIRONMENT, PEER PRESSURE AND ADOLESCENT RISK BEHAVIOUR IN BANDUNG}

\begin{abstract}
This research aims to determine the contribution of family environment and peer pressure on adolescent risk behavior in the city of Bandung. The research method used is a quantitative method with 486 respondents aged 13-18 in Bandung. The instruments in this study are from adaptations of the Family Environment Scale to measure family environments, Peer Pressure Inventory to mesuare peer pressures, and Negative Risk Behaviour Scale to measure risk behaviours. Data analysis techniques used in this study are linear regression and multiple regression. The results obtained indicate that there is an influence of family environment and peer pressure on risk behavior. The results of this study are expected to be used as a reference for families and parents in the importance of creating a positive environment in family life for their children as one of the preventive measures against the occurrence of risk behavior in adolescents.
\end{abstract}

Keyword: adolescent; family environment; peer pressure; risk behaviour

\section{PENDAHULUAN}

Masa remaja identik dengan masa penuh gejolak dan mencoba segala sesuatu hal yang baru. Masa remaja juga penuh dengan keinginan, memiliki minat yang tinggi untuk berpetualang dan mencari pengalaman baru (Dahl, 2004), serta rentan terhadap beragam psikopatologi dan masalah perilaku (Harden, dkk., 2012). Masa remaja juga merupakan masa kritis yang ditandai dengan ekplorasi dan pengambilan risiko yang tinggi (Crews, dkk., 2007; Galvan, dkk., 2006; Qu, dkk., 2015; Santelli, dkk., 2013; Michael \& Ben-Zur, 2007; Schmitz, dkk., 2004; Spear, 2000).

Perilaku berisiko merupakan perilaku yang dapat membahayakan kehidupan remaja. Hal ini sejalan dengan pendapat Landicho, dkk., (2014), bahwa perilaku berisiko merupakan suatu kecenderungan untuk terlibat dalam perilaku yang berbahaya dan dapat melukai individu. Hasil penelitian lain juga menyebutkan bahwa perilaku berisiko dapat merusak diri remaja, berdampak buruk pada kesehatan remaja, 
kesejahteraan dan bahkan bisa menyebabkan kematian pada remaja (Eaton, dkk., 2006; Ritcher, 2010). Namun, ekplorasi dan rasa ingin tahu yang tinggi pada remaja, membuat remaja tidak sadar bahwa perilaku tersebut dapat membahayakan dirinya (Santrock, 2007).

Skaar (2009), menyebutkan bahwa perilaku berisiko berpotensi menghasilkan efek yang positif dan negatif, tergantung pada konsekuensi yang didapatkan dari perilaku tersebut. Perilaku berisiko dikatakan positif jika mengarah pada pencapaian diri seperti prestasi dan dapat diterima secara sosial oleh masyarakat. Selanjutnya, perilaku berisiko dikatakan negatif jika membahayakan dan merusak diri sendiri serta meresahkan masyarakat. Penelitian ini berfokus pada perilaku berisiko negatif yang dilakukan remaja. Hal ini didasarkan pada femenoma perilaku berisiko negatif seperti perilaku merokok, alkohol, penyalahgunaan obat-obatan terlarang dan seks bebas yang cukup tinggi pada remaja di Kota Bandung.

Jabar.tribunnews.com (2018), memberitakan bahwa angka penyalahgunaan narkotika dan obatobatan terlarang di Bandung cenderung meningkat. Sepanjang tahun 2017 Polrestabes Bandung mendata terdapat 277 kasus penyalahgunaan narkoba dengan 373 orang tersangka. Begitupun jumlah remaja dalam perilaku merokok, diberitakan inews.id (2018) dan newsdetik.com (2018), berdasarkan hasil survei yang dilakukan pada 900 orang di Kota Bandung, dinyatakan bahwa $37 \%$ adalah perokok berusia 16 tahun dan sekitar $31 \%$ di antaranya telah merokok sejak berusia 15 tahun. Kemudian diberitakan pikiranrakyat.com (2018), korban jiwa alkohol ilegal di Bandung lebih tinggi dari rata-rata nasional. Terdapat satu kematian setiap 615.000 orang per tahunnya. Jumlah tersebut hampir 5 kali lipat lebih tinggi daripada rata-rata nasional. Selainjutnya, hasil survei BKKBN di Kota Surabaya, Bandung, Medan, dan Yogyakarta menunjukkan bahwa remaja Kota Bandung memiliki angka perilaku seksual yang cukup tinggi dibandingkan kota lainnya (Winingsih, dkk., 2019).

Perilaku berisiko pada remaja terjadi karena berbagai faktor, salah satunya yaitu lingkungan keluarga. Keluarga berperanan penting dalam berbagai perilaku bermasalah yang dilakukan remaja, karena keluarga merupakan lingkungan yang memengaruhi perkembangan seorang anak atau remaja (Lestari, 2012), sehingga lingkungan keluarga dapat memengaruhi kecenderungan remaja untuk terlibat dalam perilaku berisiko (Sales \& Irwin 2013; Walsh, dkk., 2010; Safronoff, dkk., 2005). Penelitian-penelitian terdahulu menyebutkan bahwa lingkungan keluarga dapat memengaruhi keterlibatan remaja dalam penggunaan zat terlarang atau narkoba (Baumrind,1987; Resnick, 1997), perilaku merokok dan alkohol (Wood, dkk., 2013) serta pergaulan seksual (Miller, dkk., 2001). Hal ini akibat kurangnya ketersediaan atau kehadiran keluarga untuk anak, serta rendahnya dukungan dan pantauan orang tua, sehingga memungkinkan remaja untuk terlibat dalam perilaku berisiko tinggi (Biglan, dkk., 1990).

Orang tua sangat berperan penting dalam lingkungan keluarga yang menjadi tempat pemberi informasi dan juga arahan agar remaja mampu mengambil keputusan yang baik dan terhindar dari perilaku negatif. Remaja yang mendapatkan dukungan dan memiliki hubungan yang positif dengan orang tuanya, memiliki kemungkinan yang lebih kecil untuk terlibat dalam perilaku berisiko (Qu, dkk., 2015; Michael \& Ben-Zur, 2007) sedangkan, remaja yang kurang mendapatkan dukungan dari keluarga dan memiliki hubungan negatif dengan orang tuanya cenderung berpartisipasi dalam perilaku berisiko (Klahr, dkk., 2011; Caffray \& Schneider, 2000; Burt, dkk., 2006). Berdasarkan paparan di atas dapat diketahui bahwa lingkungan keluarga memegang peranan penting dan berpengaruh pada keterlibatan remaja dalam perilaku berisiko.

Selain lingkungan keluarga, teman sebaya juga berpengaruh terhadap perilaku berisiko remaja. Kehadiran teman sebaya dalam situasi berisiko meningkatkan kecenderungan remaja dalam mengambil keputusan berisiko (Steinberg, 2008). Jessor dan Jessor (Sales \& Irwin, 2013) mengatakan bahwa pengaruh teman sebaya relatif dikaitkan dengan kecenderungan remaja terhadap perilaku bermasalah. Menjadi anggota kelompok sebaya adalah tugas perkembangan penting bagi remaja karena memfasilitasi remaja dalam eksplorasi diri (Santor, dkk., 2000). Namun, menjadi anggota kelompok sebaya mengharuskan individu untuk menyesuaikan diri dengan nilai-nilai dan perilaku kelompok sebaya yang mungkin tidak konsisten dengan nilai-nilai mereka sendiri. Selama periode perkembangan ini, terdapat tekanan yang kuat untuk menyesuaikan diri dengan norma teman sebaya (Arnett, 2000) yang disebut sebagai tekanan teman sebaya (Santor, dkk., 2000).

Tekanan teman sebaya merupakan suatu sikap atau persepsi sebagai pengalaman perasaan tertekan atau desakan dari teman sebaya untuk melakukan disposisi perilaku (Santrock, 2003). Tekanan dari teman sebaya dapat memengaruhi sikap, perilaku, dan keyakinan remaja serta keterlibatan remaja dalam perilaku berisiko. Berdasarkan penelitian terdahulu, tekanan teman sebaya di antara remaja menjadi prediktor kuat bagi remaja untuk terlibat dalam penggunaan alkohol (Santor, dkk., 2000; Trucco, dkk., 2011; Choo \& Shek 2013) dan perilaku seksual berisiko (Selikow, dkk., 2009).

Secara langsung maupun tidak langsung kelompok yang dimiliki remaja dapat memberikan pengaruh pada remaja untuk ikut melakukan hal serupa. Berdasarkan penelitian yang dilakukan oleh Hunter, dkk., (1991) 
ditemukan jika pola merokok dan penggunaan alkohol pada remaja yang berkelompok, memiliki pola yang sama. Pola merokok dan penggunaan alkohol pada remaja juga menyebar secara tidak langsung dengan meniru teman-teman atau orang lain yang dikagumi. Remaja menjadi terlibat dalam perilaku berisiko karena ia berusaha untuk berpartisipasi dalam pengalaman yang relevan dengan identitas kelompok dan juga untuk mencapai prestasi yang membentuk identitas diri dalam kelompok (Lightfoot, 1992) serta keinginan untuk menyenangkan teman sebaya (Allen \& Brown 2008).

Berdasarkan paparan di atas diketahui bahwa lingkungan keluarga dan teman sebaya berkontribusi terhadap perilaku berisiko yang dilakukan remaja. Kemudian, berdasarkan berita dan fenomena yang terjadi saat ini, perilaku berisiko pada remaja di Kota Bandung diketahui cukup tinggi, sehingga diperlukan penelitian mengenai faktor-faktor yang berpotensi memicu munculnya perilaku berisiko oleh remaja di Kota Bandung. Dalam penelitian ini, fokus studi diarahkan pada faktor keluarga dan teman sebaya.

\section{METODE}

Penelitian ini menggunakan pendekatan kuantitatif dengan desain korelasional untuk mengidentifikasi pengaruh lingkungan keluarga dan tekanan teman sebaya terhadap perilaku berisiko pada remaja di Kota Bandung. Responden dalam penelitain ini adalah remaja dengan rentang usia 13-18 tahun yang bersekolah SMP atau SMA di Kota Bandung. Populasi remaja dipilih karena perilaku berisiko cenderung terjadi selama masa remaja daripada saat pra-remaja atau dewasa (Steinberg, dkk 2008; Steinberg, 2007; Duell \& Steinberg, 2018). Kemudian, peneliti memilih subjek SMP dan SMA karena berdasarkan data Statistik Daerah Kota Bandung (2018), persentase remaja usia 13-18 tahun yang bersekolah sebesar $85,6 \%$ dan yang tidak bersekolah/ putus sekolah sebesar 14,4\%, sehingga populasi remaja di Bandung dapat diwakili oleh remaja yang bersekolah.

Teknik sampling yang digunakan adalah probability sampling dengan multistages cluster random sampling (Creswell, 2015), karena obyek yang diteliti atau sumber data yang luas. Pengambilan sampel untuk menentukan sekolah mana yang akan dijadikan sumber data, berdasarkan daerah populasi yang ditetapkan dalam penelitian ini yaitu seluruh SMP dan SMA seKota Bandung yang terbagi ke dalam 6 cluster, yaitu Bojonagara, Cibeunying, Tegalega, Karees, Ujung Berung, dan Gedebage.

Penarikan sampel dalam penelitian ini dilakukan melalui beberapa tahap. Tahap pertama dalam proses pengambilan sampel yaitu dengan menentukan sampel sekolah. Sampel sekolah dalam penelitian ini ditentukan dari populasi SMP dan SMA di Kota Bandung. Jumlah SMP di Kota Bandung sebanyak 239 sekolah dan SMA sebanyak 132 sekolah dengan keseleruhan 371 sekolah. Kemudian, diambil sebanyak $10 \%$ dari jumlah sekolah tersebut, karena populasi berada dalam jumlah yang besar, yaitu SMP dan SMA se-Kota Bandung (Arikunto, 2006; 2009). Jadi, total sekolah yang akan dijadikan sampel yaitu 37 sekolah yang terdiri dari tingkat SMP dan SMA. Setelah diperoleh total dari sekolah yang akan dijadikan sampel, ditentukan jumlah sampel sekolah baik SMP dan SMA di setiap cluster.

Selanjutnya, peneliti memilih secara acak sekolahsekolah yang akan dijadikan sampel di setiap cluster tersebut. Kemudian, setelah sampel sekolah diperoleh dan sekolah-sekolah telah dipilih, tahap selanjutnya adalah menentukan jumlah populasi dan sampel siswa. Populasi siswa dalam penelitian ini sebanyak 29.570 remaja SMP dan SMA. Populasi siswa diambil dari jumlah siswa SMP dan SMA se-kota Bandung yang terpilih. Penghitungan sampel siswa dilakukan dengan rumus Slovin dengan hasil 395, sehingga jumlah sampel minimal dalam penelitian ini adalah sebanyak 395 responden.

Setelah dilakukan pengambilan data, diperoleh sampel sebanyak 486 remaja, karena pada beberapa sampel sekolah kuesioner dibagikan melebihi jumlah perhitungan yang sudah ditentukan, untuk menghindari adanya data yang rusak atau tidak bisa digunakan. Adapun gambaran demografis responden lebih rinci dijelaskan pada tabel di bawah ini:

\section{Tabel 1. Gambaran Demogafis Responden}

\begin{tabular}{cccc}
\hline Data & Karakteristik & Frekuensi & Persentase \\
Demografi & & & \\
\hline Jenis & Laki-Laki & 183 & $38 \%$ \\
\cline { 2 - 4 } & Perempuan & 303 & $62 \%$ \\
\cline { 2 - 4 } & Jumlah & $\mathbf{4 8 6}$ & $\mathbf{1 0 0 \%}$ \\
\hline Usia & 13 tahun & 53 & $11 \%$ \\
\cline { 2 - 4 } & 14 tahun & 145 & $30 \%$ \\
\cline { 2 - 4 } & 15 tahun & 91 & $19 \%$ \\
\cline { 2 - 4 } & 16 tahun & 90 & $19 \%$ \\
\cline { 2 - 4 } & 17 tahun & 93 & $19 \%$ \\
\cline { 2 - 4 } Jenjang & 18 tahun & 14 & $3 \%$ \\
\cline { 2 - 4 } Sekolah & Jumlah & $\mathbf{4 8 6}$ & $\mathbf{1 0 0 \%}$ \\
\cline { 2 - 4 } & SMP & 236 & $49 \%$ \\
\cline { 2 - 4 } Tinggal & SMA & 250 & $51 \%$ \\
Bersama & Jumlah & $\mathbf{4 8 6}$ & $\mathbf{1 0 0 \%}$ \\
\cline { 2 - 4 } & Ayah dan Ibu & 418 & $86 \%$ \\
\cline { 2 - 4 } & Ayah & 13 & $3 \%$ \\
\cline { 2 - 4 } & Ibu & 38 & $8 \%$ \\
\cline { 2 - 4 } & Wali & $\mathbf{4 8 6}$ & $\mathbf{1 0 0 \%}$ \\
\cline { 2 - 4 } & Jumlah & & \\
& & &
\end{tabular}

Teknik pengumpulan data menggunakan kuesioner. Kuesioner berupa instrumen Family Environment Scale (FES), Peer Pressure Inventory 
(PPI) dan Negative Risk Behaviour Scale yang sudah diadapatasi dan kemudian diujicobakan. Hasil uji coba menunjukkan bahwa instrumen FES menmiliki koefisien reliabilitas alpha sebesar 0.83, PPI sebesar 0.73 dan Negative Risk Behaviour Scale sebesar 0.72, sehingga ketiga instrumen dapat dikatakan reliabel.

Kuesioner yang dibagikan kepada responden berisi informed consent, identitas diri responden yang kemudian dilanjutkan dengan pernyataan-pernyataan mengenai variabel penelitian yaitu lingkungan keluarga, tekanan teman sebaya dan perilaku berisiko yang telah diujicobakan. Kuesioner disebarkan ke sekolah-sekolah yang telah dipilih menjadi sampel penelitian. Penyebaran kuesioner dilakukan pada tanggal 29 Agustus sampai 24 September 2019.

Penyebaran kuesioner dilakukan secara offline dan juga online. Kuesioner offline diberikan kepada 323 responden, sedangkan kuesioner online diisi 163 responden. Penyebaran kuesioner offline dilakukan dengan mendatangi langsung sekolah-sekolah yang sudah dipilih menjadi sampel penelitian. Kemudian peneliti juga menitipkan kuesioner kepada kenalan atau rekan yang mengajar ataupun mempunyai kenalan dengan siswa dari sampel sekolah, untuk kemudian dibagikan secara langsung kepada anak-anak yang bersekolah di sekolah tersebut.

Selanjutnya, karena banyaknya sampel sekolah dalam penelitian serta keterbatasan waktu dan juga biaya, peneliti membuat kuesioner online dalam bentuk google form dengan tautan http://bit.ly/BantuSkripsiTania. Peneliti menyebarkan kuesioner online dengan cara memanfaatkan media sosial. Peneliti mengirimkan tautan google form ke akun sekolah ataupun OSIS melalui Instagram dan juga Line. Peneliti juga membuat poster dan meminta bantuan kepada teman-teman yang memiliki kenalan dengan siswa sekolah-sekolah yang menjadi sampel penelitian untuk membagikan poster beserta tautan google form kepada siswa yang bersangkutan. Jadi, meskipun penyebaran kuesioner dilakukan secara online, kuesioner tetap tertuju langsung ke sampel sekolah yang sudah dipilih.

Teknik analisis data dalam penelitian menggunakan bantuan software SPSS 20.0 dengan melakukan uji regeresi berganda untuk mengetahui pengaruh lingkungan keluarga dan tekanan teman sebaya terhadap perilaku berisiko remaja di kota Bandung. Sebelum dilakukan analisis regresi, peneliti melakukan transformasi data dari ordinal dan nominal ke rasio melalui pemodelan rasch dengan menggunakan aplikasi winstep. Proses transformasi data dilakukan karena syarat dari uji analisis regresi adalah data yang dapat diolah harus berbentuk data interval atau rasio (Sumintono \& Widhiarso, 2013). Skor item total yang telah diubah menjadi data rasio melalui aplikasi winstep selanjutnya digunakan untuk kategorisasi skala dan analisis regresi. Taraf signifikansi untuk hasil analisis regresi yang digunakan dalam penelitian ini yaitu jika signifikan $(\alpha) \leq 0.05$, maka $\mathrm{H}_{0}$ ditolak dan jika signifikan $(\alpha)>0.05$, maka $\mathrm{H}_{0}$ tidak ditolak.

\section{HASIL DAN PEMBAHASAN}

Setelah dilakukan pengambilan data, diperoleh sampel sebanyak 486 remaja yang berusia 13-18 tahun dan bersekolah SMP dan SMA di Kota Bandung dengan hasil analisis sebagai berikut:

Tabel 2. Hasil Uji Regresi Berganda Lingkungan Keluarga dan Tekanan Teman Sebaya terhadap Perilaku Berisiko

\begin{tabular}{|c|c|c|c|c|}
\hline Model & $\boldsymbol{\beta}$ & Sig. & $\begin{array}{c}\mathbf{R} \\
\text { Square }\end{array}$ & Sig. \\
\hline (Constant) & 22,002 & 0,000 & 0,150 & $0,000^{*}$ \\
\hline $\begin{array}{c}\text { Lingkungan } \\
\text { Keluarga }\end{array}$ & $-0,626$ & 0,000 & & \\
\hline $\begin{array}{c}\text { Tekanan } \\
\text { Teman } \\
\text { Sebaya }\end{array}$ & 1,351 & 0,000 & & \\
\hline
\end{tabular}

Tabel 2. menunjukkan nilai $R_{\text {square }}$ sebesar 0,150 yang artinya perilaku berisiko dipengaruhi $15 \%$ oleh variabel lingkungan keluarga dan tekanan teman sebaya. Sedangkan sisanya $85 \%$ perilaku berisiko dipengaruhi oleh faktor-faktor lain selain lingkungan keluarga dan tekanan teman sebaya. Nilai signifikansi lingkungan keluarga dan tekanan teman sebaya terhadap perilaku berisiko sebesar $0,000 \quad(<0,05)$ maka $\mathrm{H}_{0}$ ditolak, sehingga model regresi berganda dapat digunakan untuk memprediksi perilaku berisiko.

Berikut adalah persamaan regresi untuk melihat besaran pengaruh lingkungan keluarga dan tekanan teman sebaya terhadap perilaku berisko:

$$
Y=-22.002-0.626 X_{1}+1.351 X_{2}
$$

Persamaan tersebut memiliki nilai (constant) sebesar -22,002, nilai lingkungan keluarga sebesar 0,626 dan nilai tekanan teman sebaya sebesar 1,351 . Artinya jika tidak ada lingkungan keluarga dan tekanan teman sebaya, maka perilaku berisiko sebesar -22,002 pada remaja di Kota Bandung. Namun, jika ada satu poin lingkungan keluarga naik, maka perilaku berisiko berkurang sebesar $-0,626$.

Selanjutnya, ketika pengaruh lingkungan keluarga dikendalikan, maka pada saat tekanan teman sebaya naik 
satu satuan, perilaku berisiko naik sebesar 1,351. Hasil analisis menunjukkan bahwa tekanan teman sebaya meningkatkan perilaku berisiko dan lingkungan keluarga mengurangi perilaku berisiko pada remaja di Kota Bandung.

Lingkungan keluarga dapat mencegah dan mengurangi keterlibatan remaja dari pengaruh teman sebaya terhadap perilaku berisiko. Jika tidak ada lingkungan keluarga, pada saat satu poin tekanan teman sebaya naik, perilaku berisiko naik sebesar 1,633. Namun, ketika pengaruh lingkungan keluarga dikendalikan, pada saat tekanan teman sebaya naik satu satuan, perilaku berisiko naik sebesar 1,351. Hasil ini menunjukkan bahwa lingkungan keluarga dapat mengurangi keterlibatan remaja dalam perilaku berisiko, meskipun terdapat pengaruh tekanan teman sebaya.

Hasil penelitain ini didukung oleh penelitianpenelitian sebelumnya. Sullivan (2006), dalam penelitiannya mengatakan bahwa tekanan teman sebaya merupakan prediktor terkuat dalam perilaku penyimpangan remaja, sedangkan lingkungan keluarga memberikan efek perlindungan dari perilaku penyimpangan tersebut. Remaja dengan tekanan teman sebaya yang tinggi akan cenderung terlibat dalam perilaku berisiko. Namun, lingkungan keluarga yang positif dapat menurunkan perilaku berisiko tersebut, karena pengembangan diri yang baik, kualitas hubungan yang positif, serta sistem kontrol yang kuat dalam keluarga dapat melindungi remaja untuk terlibat dalam perilaku berisiko.

Sejalan dengan itu, Michael \& Ben-Zur (2007) dalam penelitiannya menemukan bahwa hubungan yang positif antara remaja dan orang tua dikaitkan dengan pengambilan risiko yang lebih sedikit, sementara orientasi yang kuat terhadap kelompok sebaya dikaitkan dengan berisiko yang lebih tinggi. Hubungan yang baik dengan orang tua terkait dengan rendahnya keterlibatan dalam perilaku pengambilan risiko di kalangan remaja, sementara hubungan yang lebih kuat dengan teman sebaya terkait dengan keterlibatan tinggi dalam pengambilan risiko. Penelitian Michael \& Ben-Zur menunjukkan bahwa hubungan positif antara remaja dan orang tua memiliki efek langsung negatif yang signifikan terhadap pengambilan risiko, sedangkan orientasi terhadap kelompok sebaya memiliki efek langsung positif yang signifikan.

Lopez, dkk., (2008) dalam penelitiannya juga menyebutkan bahwa remaja dengan lingkungan keluarga yang positif cenderung tidak terlibat dalam perilaku berisiko. Hal tersebut dikarenakan remaja dengan lingkungan keluarga positif mendapatkan dukungan dan memiliki hubungan yang positif dengan orang tuanya, sehingga memiliki kemungkinan yang lebih kecil untuk terlibat dalam perilaku pengambilan risiko (Qu, dkk., 2015).
Kualitas hubungan orang tua dan anak berpengaruh terhadap perilaku yang akan ditampilkan anak (Burt, dkk., 2006). Hubungan positif dan stabil antara orang tua dan anak menghasilkan lingkungan di rumah yang lebih positif. Sehingga anak dapat mengandalkan dukungan dan bimbingan moral dari orang tua dan orang tua bertindak sebagai panutan dan contoh otentik dari nilai dan norma. Dengan demikian, orang tua lebih dapat memantau perilaku anak sehingga kecenderungan untuk terlibat dari perilaku berisiko lebih sedikit (Michael \& Ben-Zur, 2007).

Lebih lanjut Turner, dkk., (1993), dalam penelitiannya menemukan bahwa remaja yang mendapatkan dukungan emosional, penerimaan, dan juga memiliki hubungan yang baik dengan orangtuanya cenderung tidak menyalahgunakan zat dan memulai aktivitas seksual. Kemudian, penelitian lainnya menemukan bahwa hubungan orang tua-anak yang di dalamnya terdapat dukungan, kedekatan, dan kehangatan dapat mencegah risiko kehamilan dan seks bebas pada remaja (Miller, dkk., 2001). Begitupun mengenai pengawasan dan kontrol orang tua, ditemukan bahwa orang tua dengan pengawasan dan sistem kontrol yang baik, dapat mengurangi keterlibatan remaja untuk melakukan perilaku seksual berisiko atau seks bebas (Miller, dkk., 2001).

Remaja yang memiliki lingkungan keluarga yang negatif cenderung berpartisipasi dalam perilaku berisiko (Caffray \& Scheneider, 2000). Hal ini juga didukung oleh Klahr, dkk., (2011), yang mengatakan bahwa remaja yang kurang mendapatkan dukungan dari keluarga memiliki kemungkinan lebih besar untuk melakukan perilaku berisiko dan perilaku anti sosial. Biglan, dkk., (1990), menambahkan bahwa kurangnya ketersediaan atau kehadiran keluarga untuk anak, serta rendahnya dukungan dan pantauan orang tua, memungkinkan remaja untuk terlibat dalam perilaku berisiko tinggi.

Kualitas hubungan yang negatif dalam keluarga yang ditandai dengan tingkat konflik yang tinggi dan ikatan emosional yang rendah antara remaja dan orang tua menyebabkan tingginya perilaku menyimpang pada remaja (Dekovic, 1999). Sejalan dengan itu, DiClemente, dkk., (2010), menyebutkan bahwa hubungan orang tua-remaja yang ditandai dengan konflik dan tidak responsif serta adanya peningkatan jarak emosional dalam keluarga, meningkatkan kemungkinan remaja untuk terlibat dalam perilaku yang membahayakan kesehatan.

Selanjutnya, mengenai teman sebaya, Brown, dkk., (1986) dalam penelitiannya mengatakan bahwa tekanan teman sebaya memengaruhi remaja untuk terlibat dalam berbagai perilaku bermasalah seperti perilaku berisiko. Masa remaja rentan dengan tekanan dari lingkungan sekitarnya, khususnya dari teman 
sebaya. Pada saat melalui perubahan dalam hidupnya, remaja butuh terlibat dengan teman sebaya untuk memiliki identitas dan tidak merasa sendirian menghadapi masa-masa yang dilaluinya. Hal tersebut membuat remaja rentan mengalami tekanan teman sebaya (Clark, 2009).

Kelompok teman sebaya dapat berfungsi sebagai dukungan sosial sekaligus sumber godaan dan bahaya bagi remaja. Hal ini terjadi karena melalui teman sebaya, remaja rentan untuk menerima tekanan dari temannya dalam menyesuiakan norma kelompok (Arnett, 2000). Tekanan teman sebaya mendorong keterlibatan remaja dalam tindakan berbahaya, dengan sosialisasi dalam kelompok sebaya yang mengarahkan remaja pada perilaku pengambilan risiko (Diblasio, 1986), karena tekanan teman sebaya memengaruhi sikap, perilaku, dan keyakinan remaja (Clasen \& Brown, 1985).

Penelitian-penelitian sebelumnya menemukan bahwa tekanan teman sebaya di antara remaja menjadi prediktor kuat bagi remaja untuk terlibat dalam penggunaan alkohol (Trucco, dkk, 2011; Choo \& Shek 2013; Peacock \& Bruno, 2015), perilaku seksual berisiko (Selikow, dkk., 2009; Crockett, dkk., 2006), aksi kebut-kebutan di jalan (Gheorghiu, dkk., 2015) dan penyesuaian sosial remaja (Oni, 2010).

Perilaku-perilaku berisiko tersebut dilakukan remaja bersama teman sebayanya karena berusaha untuk berpartisipasi dalam pengalaman yang tampak relevan dengan identitas kelompok atau sebagai bentuk loyalitas terhadap dan sebagai anggota kelompok serta kesesuaian dalam menerapkan nilai-nilai kelompoknya (Michael\&Ben-Zur, 2007; Lightfoot, 1992). Kemudian, remaja ingin mencapai prestasi yang membentuk identitas diri dalam kelompoknya (Lightfoot, 1992) serta adanya keinginan dalam diri remaja untuk menyenangkan teman sebayanya (Allen \& Brown, 2008).

Remaja yang memiliki orientasi kuat terhadap kelompok sebaya akan cenderung mengikuti harapan rekan-rekan kelompok dan akan terpengaruh oleh sikap dan tindakan kelompoknya, sehingga lebih mungkin terlibat dalam perilaku berisiko dibandingkan remaja dengan orientasi yang lemah terhadap kelompok sebaya (Michael\&Ben-Zur, 2007).

Masa remaja merupakan masa transisi berganda, yaitu transisi menuju masa pubertas dan transisi yang melibatkan hubungan keluarga, dan juga teman sebaya (Michael\&Ben-Zur, 2007). Masa remaja penuh dengan kebingungan, pencarian identitas diri, dan keinginan untuk mencoba hal-hal baru yang membuat remaja mudah terpengaruh oleh lingkungan sekitar (Martha, 2008). Remaja cenderung menyesuaikan diri dengan lingkungan baru dengan mengikut kelompok-kelompok yang ada di sekitarnya. Penyesuaian diri yang dilakukan remaja tersebut membuat remaja rentan untuk mendapat tekanan dari teman sebayanya (Arnet, 2000). Remaja yang mendapat tekanan dari teman sebaya rentan terhadap perilaku berisiko (Yuksel-Sahin, 2015; Hidayati, 2015).

Oleh karena itu, pada masa remaja ini dibutuhkan perlindungan keluarga, terutama orang tua dalam mengontrol perilaku remaja dan membentuk lingkungan yang positif dalam keluarga. Keluarga berperan penting dalam berbagai perilaku bermasalah yang dilakukan remaja, karena keluarga adalah lingkungan yang memengaruhi perkembangan remaja (Lestari, 2012). Peran orang tua dibutuhkan untuk memberikan dukungan dan bantuan serta membentuk lingkungan yang positif dalam keluarga agar keluarga dapat menjalankan fungsinya dengan baik, sehingga dapat mencegah remaja untuk terlibat dalam perilaku yang negatif (Abu Bakar, dkk., 2016).

\section{SIMPULAN}

Kesimpulan dari penelitian ini yaitu terdapat pengaruh lingkungan keluarga dan tekanan teman sebaya terhadap perilaku berisiko remaja di Kota Bandung. Lingkungan keluarga yang positif, memberi konstribusi meskipun tidak besar, untuk mengurangi perilaku berisiko pada remaja. Tekanan teman sebaya yang tinggi berpeluang kuat untuk meningkatkan perilaku berisiko pada remaja. Artinya, ketika tekanan teman sebaya meningkat, maka dapat diprediksikan perilaku berisiko juga akan meningkat. Peneliti selanjutnya diharapkan dapat melakukan penelitian lebih lanjut dengan menggali lebih spesifik mengenai latar belakang keluarga responden, seperti status tinggal responden, pendidikan orangtua, status ekonomi keluarga, jumlah anggota keluarga dan sebagainya. Adapun keterbatasan dalam penelitian ini adalah sebagai berikut:

a. Sampel sekolah pada penelitian ini cukup banyak dan jarak tempuh beberapa sampel sekolah cukup jauh, sehingga peneliti tidak hanya melakukan pengambilan data secara offline, namun juga dengan bantuan online.

b. Jumlah item pada instrumen penelitian ini terhitung banyak, sehingga adanya kemungkinan remaja mengalami kejenuhan saat pengisian kuesioner. Hal ini juga mungkin menyebabkan adanya kuesioner yang tidak diisi secara utuh atau diisi asal-asalan oleh remaja, sehingga ada beberapa data yang tidak dapat digunakan.

\section{DAFTAR PUSTAKA}

Abu Bakar, S. H., Wahab, H. A., \& Rezaul Islam, M. (2016). Parental attachment for at-risk children's 
antisocial behaviour: A case of Malaysia. Child care in practice, 22(2), 148-165.

Allen, J. P., \& Brown, B. B. (2008). Adolescents, peers, and motor vehicles: the perfect storm?. American journal of preventive medicine, 35(3), S289-S293.

Arnett, J. J. (2000). Emerging adulthood: A theory of development fr om the late teens through the twenties. American psychologist, 55(5), 469.

Badan Pusat Statistik Kota Bandung. (2018). Statistik Daerah Kota Bandung 2018. Handbook.

Baumrind, D. (1987). A developmental perspective on adolescent risk taking in contemporary America. New directions for child and adolescent development, 1987(37), 93-125.

Biglan, A., Metzler, C. W., Wirt, R., Ary, D., Noell, J., Ochs, L., ... \& Hood, D. (1990). Social and behavioral factors associated with high-risk sexual behavior among adolescents. Journal of behavioral medicine, 13(3), 245-261.

Brown, B. B., Clasen, D. R., \& Eicher, S. A. (1986). Perceptions of peer pressure, peer conformity dispositions, and self-reported behavior among adolescents. Developmental psychology, 22(4), 521.

Burt, S. A., McGue, M., Lacono, W. G., \& Krueger, R. F. (2006). Differential parent-childrelationships and adolescent externalizing symptoms: Crosslagged analyses within a monozygotic twin differences design. Devevelopmental Psychology, 42, 1289-1298.

Caffray, C. M., \& Schneider, S. L. (2000). Why do they do it? Affective motivators in adolescents' decisions to participate in risk behaviours. Cognition \& Emotion, 14(4), 543-576.

Choo, H., \& Shek, D. (2013). Quality of parent-child relationship, family conflict, peer pressure, and drinking behaviors of adolescents in an Asian context: The case of Singapore. Social indicators research, 110(3), 1141-1157.

Clark, K S., Murphy, M. M., Bnas, S. L. (2009). Handling Peer Pressure. New York: Infobase, 14$19,80-81$.

Clasen, D. R., \& Brown, B. B. (1985). The multidimensionality of peer pressure in adolescence. Journal of youth and adolescence, 14(6), 451-468.

Creswell, J, C. (2015). Riset Pendidikan: Perencanaan, Pelaksanaan dan Evaluasi Riset Kualitatif dan Kuantitatif. Edisi Kelima. (Terjemahan). Yogyakarta : Pustaka Pelajar

Creswell, J.C. (2012). Education Research, Planning, Conducting and Evaluating Quantitative and Qualitative Research. 4th edition. Boston: Pearson

Crews, F., He, J., \& Hodge, C. (2007). Adolescent cortical development: a critical period of vulnerability for addiction. Pharmacology Biochemistry and Behavior, 86(2), 189-199.

Crockett, L. J., Raffaelli, M., \& Shen, Y. L. (2006). Linking self-regulation and risk proneness to risky sexual behavior: Pathways through peer pressure and early substance use. Journal of Research on Adolescence, 16(4), 503-525.

Dahl, R. E. (2004). Adolescent brain development: a period of vulnerabilities and opportunities. Keynote address. Annals of the New York Academy of Sciences, 1021(1), 1-22.

Dekovic', M. (1999). Risk and protective factors in the development of problem behavior during adolescence. Journal of Youth and Adolescence, 28, 667-685.

DiClemente, R. J., Santelli, J. S., \& Crosby, R. A. (Eds.). (2009). Adolescent health: Understanding and preventing risk behaviors. John Wiley \& Sons.

Duell, N., \& Steinberg, L. (2018). Positive risk taking in adolescence. Child Development Perspectives. 0 (0), 1-5

Eaton, D. K., Kann, L. \& Kinchen, S. (2006). Youth risk behavior surveillance. Division of Adolescent and School Health, National Center for Chronic Disease Prevention and Health Promotion, 55(5), 1-108.

Galvan, A., Hare, T. A., Parra, C. E., Penn, J., Voss, H., Glover, G., \& Casey, B. J. (2006). Earlier development of the accumbens relative to orbitofrontal cortex might underlie risk-taking behavior in adolescents. Journal of Neuroscience, 26(25), 6885-6892.

Gheorghiu, A., Delhomme, P., \& Felonneau, M. L. (2015). Peer pressure and risk taking in young drivers' speeding behavior. Transportation research part F: traffic psychology and behaviour, 35, 101-111.

Harden, K. P., Quinn, P. D., \& Tucker-Drob, E. M. (2012). Genetically influenced change in sensation seeking drives the rise of delinquent behavior during adolescence. Developmental science, 15(1), 150-163.

Hunter, S. M., Vizelberg, I. A., \& Berenson, G. S. (1991). Identifying mechanisms of adoption of tobacco and alcohol use among youth: The Bogalusa heart study. Social Networks, 13(1), 91104.

Newsdetik.com. (2018). 37 Persen Perokok di Kota Bandung Masih Usia Sekolah. [online]. https://news.detik.com/berita-jawa-barat/d3832999/37-persen-perokok-di-kota-bandungmasih-usia-sekolah Diakses 26 Desember 2018

Klahr, A. M., McGue, M., Lacono, W. G., \& Burt, S. A. (2011). The association between parent-child conflict and adolescent conduct problems over 
time: Results from a longitudinal adoption study. Journal Abnormal Psychology, 120, 46-56.

Landicho, D. L. C., Cabanig, M. C. A., Cortes, M. S. F., \& Villamor, B. J. B. (2014). Egocentrism and risktaking among adolescents. APJMR, 2(3).

Lestari, Sri. (2012). Psikologi Keluarga: Penanaman Nilai dan Penanganan Konflik dalam Keluarga. Jakarta : Prenadamedia Group.

Lightfoot, C. (1992). Constructing self and peer culture: A narrative perspective on adolescent risk taking. Children's development within social context, 2, 229-245.

López, E. E., Pérez, S. M., Ochoa, G. M., \& Ruiz, D. M. (2008). Adolescent aggression: Effects of gender and family and school environments. Journal of Adolescence, 31(4), 433-450.

Michael, K., \& Ben-Zur, H. (2007). Risk-taking among adolescents: Associations with social and affective factors. Journal of adolescence, 30(1), 17-31.

Miller, B. C., Benson, B., \& Galbraith, K. A. (2001). Family relationships and adolescent pregnancy risk: A research synthesis. Developmental review, 21(1), 1-38.

Oni, A. A. (2010). Peer group pressure as a determinant of adolescent social adjustment in Nigerian schools. Journal of Educators \& Education/Jurnal Pendidik dan Pendidikan, 25.

Inews.id. (2018). Kasus Perokok Pemula di Kota Bandung Terus Meningkat. [online]. Tersedia: https://www.inews.id/daerah/jabar/41141/kasusperokok-pemula-di-kota-bandung-terusmeningkat Diakses 26 Desember 2018

Peacock, A., \& Bruno, R. (2015). Young adults who mix alcohol with energy drinks: typology of risk-taking behaviour. Addictive behaviors, 45, 252-258.

Qu, Y., Fuligni, A. J., Galvan, A., \& Telzer, E. H. (2015). Buffering effect of positive parent-child relationships on adolescent risk taking: a longitudinal neuroimaging investigation. Developmental cognitive neuroscience, 15, 26-34.

Resnick, M. D., Bearman, P. S., Blum, R. W., Bauman, K. E., Harris, K. M., Jones, J., ... \& Ireland, M. (1997). Protecting adolescents from harm: findings from the National Longitudinal Study on Adolescent Health. Jama, 278(10), 823-832.

Richter, M. (2010). Conceptual framework. Risk Behaviour in Adolescence, 25-44. doi:10.1007/978-3-531-92364-2_2

Sales, J. M., \& Irwin, C. E. (2013). A biopsychosocial perspective of adolescent health and disease. In Handbook of adolescent health psychology (pp. 13-29). Springer, New York, NY.

Santelli, J. S., Sivaramakrishnan, K., Edelstein, Z. R., \& Fried, L. P. (2013). Adolescent risk-taking, cancer risk, and life course approaches to prevention. Journal of Adolescent Health, 52(5), S41-S44.

Santor, D. A., Messervey, D., \& Kusumakar, V. (2000). Measuring peer pressure, popularity, and conformity in adolescent boys and girls: Predicting school performance, sexual attitudes, and substance abuse. Journal of youth and adolescence, 29(2), 163-182.

Santrock, J, W. (2003). Adolescence : Perkembangan Remaja. Jakarta: Erlangga

Santrock, J, W. (2007). Perkembangan Anak. Jilid 1. Edisi Kesebelas. Jakarta : Erlangga

Schmitz, K. E., Hovell, M. F., Nichols, J. F., Irvin, V. L., Keating, K., Simon, G. M., ... \& Jones, K. L. (2004). A validation study of early adolescents' pubertal self-assessments. The Journal of Early Adolescence, 24(4), 357-384.

Selikow, T. A., Ahmed, N., Flisher, A. J., Mathews, C., \& Mukoma, W. (2009). I am not "umqwayito": A qualitative study of peer pressure and sexual risk behaviour among young adolescents in Cape Town, South Africa. Scandinavian Journal of Public Health, 37(2_suppl), 107-112.

Skaar, N. R. (2009). Development of the adolescent exploratory and risk behavior rating scale. Disertasi.

Spear, Linda, P. (2000). Neurobehavioral Changes is Adolescence. American Psychological Society. 9 (4). hlm 1-4.

Steinberg, L. (2007). Risk taking in adolescence: New perspectives from brain and behavioral science. Current directions in psychological science, 16(2), 55-59.

Steinberg, L. (2008). A social neuroscience perspective on adolescent risk-taking. Developmental review, 28(1), 78-106.

Sullivan, C. J. (2006). Early adolescent delinquency: Assessing the role of childhood problems, family environment, and peer pressure. Youth violence and juvenile justice, 4(4), 291-313.

Sumintono, B dan Widhiarso, W. (2013). Aplikasi model Rasch untuk Penelitian Sosial. Cimahi: Trim Komunikata Publishing House.

Survei Demografi dan Kesehatan Indonesia. (2017). Kesehatan reproduksi remaja. Badan Pusat Statistik. Jakarta: Indonesia.

Jabar.tribunnews. (2018). Penyalahgunaan Narkotika di Bandung Meningkat, BNN dan Pemkot Bandung Nyatakan 'Perang'. Tersedia: http://jabar.tribunnews.com/2018/07/28/penyalah gunaan-narkotika-dibandung-meningkat-bnn-danpemkot-bandung-nyatakan-perang. Diakses 17 Desember 2018.

Trucco, E. M., Colder, C. R., Bowker, J. C., \& Wieczorek, W. F. (2011). Interpersonal goals and 
susceptibility to peer influence: Risk factors for intentions to initiate substance use during early adolescence. The Journal of early adolescence, 31(4), 526-547.

Turner, R. A., Irwin, C. E., Tschann, J. M., \& Millstein, S. G. (1993). Autonomy, relatedness, and the initiation of health risk behaviors in early adolescence. Health Psychology, 12(3), 200.

Wood, A. P., Dawe, S., \& Gullo, M. J. (2013). The role of personality, family influences, and prosocial risk-taking behavior on substance use in early adolescence. Journal of adolescence, 36(5), 871881.

Yüksel-Şahin, F. (2015). Predicting Peer Pressure Levels Among Turkish Adolescents. ProcediaSocial and Behavioral Sciences, 191, 1807-1812 